\title{
Lithium carbonate as add-on therapy to radioiodine in the treatment on hyperthyroidism: a systematic review and meta-analysis
}

Mohamed Abd-ElGawad ${ }^{1 *}$ (D) Mohamed Abdelmonem', Ahmed Eissa Ahmed ${ }^{1}$, Omar Magdy Mohammed', Mohamed Sayed Zaazouee ${ }^{2}$, Ahmed Assar ${ }^{3}$, Mohamed Gadelkarim ${ }^{4}$ and Ahmed M. Afifi ${ }^{5}$

\begin{abstract}
Background: The main purpose is to investigate the effect of LiCO3 as an add-on therapy with radioactive iodine in increasing the cure and decreasing the T4 level compared to radioactive iodine alone. The primary outcome is the cure rate as defined by the number of hyperthyroid patients who became euthyroid or hypothyroid. The secondary outcome is the T4 level.

Methods: Four databases were searched (PubMed, Scopus, Web of Science, and Cochrane central library). The inclusion criteria were randomized and non-randomized clinical trials of hyperthyroidism patients receiving LiCO3 with radioiodine compared with hyperthyroidism patients receiving radioactive iodine alone. Included studies were appraised with the risk of bias version 2 tool, according to the Cochrane Handbook for Systematic Reviews of Interventions 5.1.0.

Results: Nine studies were eligible for inclusion in the study, six randomized control trials and three nonrandomized control trials. There were 477 patients in the intervention group and 451 patients in the control group. The cure rate was not significantly different between the two groups, while it was significantly increased with 5000 to $6500 \mathrm{mg}$ optimized cumulative dose of LiCO3 compared with the control group, $P=0.0001$. The T4 level showed no significant difference between the two groups, $P=0.13$.

Conclusions: $\mathrm{LiCO} 3$ adjunct to radioactive iodine did not show significant differences compared with radioactive iodine alone in terms of cure rate or decreasing T4 level. However, the dose of 5000 to $6000 \mathrm{mg}$ of LiCO3 may increase the cure rate.
\end{abstract}

Keywords: Hyperthyroidism, Lithium carbonate, Radioactive iodine, Cure rate

\footnotetext{
* Correspondence: mohammed.mahmod87@gmail.com

${ }^{1}$ Faculty of Medicine, Fayoum University, 5 Al-Touba Street, from Al-Fanya

Street, Al-Hadka road, Fayoum, Fayoum, Egypt

Full list of author information is available at the end of the article
}

(c) The Author(s). 2021 Open Access This article is licensed under a Creative Commons Attribution 4.0 International License, which permits use, sharing, adaptation, distribution and reproduction in any medium or format, as long as you give appropriate credit to the original author(s) and the source, provide a link to the Creative Commons licence, and indicate if changes were made. The images or other third party material in this article are included in the article's Creative Commons licence, unless indicated otherwise in a credit line to the material. If material is not included in the article's Creative Commons licence and your intended use is not permitted by statutory regulation or exceeds the permitted use, you will need to obtain permission directly from the copyright holder. To view a copy of this licence, visit http://creativecommons.org/licenses/by/4.0/ The Creative Commons Public Domain Dedication waiver (http://creativecommons.org/publicdomain/zero/1.0/) applies to the data made available in this article, unless otherwise stated in a credit line to the data. 


\section{Background}

Hyperthyroidism is a syndrome in which the thyroid gland is secreting large amounts of thyroid hormones as thyroxin (T4) and triiodothyronine (T3) [1]. It has some causes as Graves' disease which is an autoimmune disease characterized by the presence of the anti-thyroid stimulating hormone (TSH), receptor antibodies with overproduction of T3 and T4 [2, 3], autonomous nodule or nodules with overproduction of thyroid hormones, some forms of thyroiditis with damage of thyroid follicles which resulted in the irregular release of T3 and T4, thyroid tumor or toxic goiter [1].

An initial approach to the treatment of hyperthyroidism is by administrating anti-thyroid drugs and aiming to reduce the production of thyroid hormones [4]. However, population-based studies [5] showed that anti-thyroid drugs might be associated with sudden cardiac death (3.9\%). Besides, they had rare serious side effects as agranulocytosis, vasculitis, or hepatic injury which were considered as signs to stop these drugs [1]. The literature reported other less serious side effects as fever, pruritus, rash, arthralgia, gastrointestinal distress, and abnormal taste sensation [6]. Besides, this treatment is likely to fail after 18 months, and the recurrence of hyperthyroidism ensues [7]. Thus, nowadays, recommended treatments include radioiodine (RAI) therapy or thyroidectomy $[4,8]$.

Physicians at the Massachusetts General Hospital in Boston have used radioiodine in the treatment of thyrotoxicosis since 1941 [9, 10]. Owing to its convenient eight-day half-life and being an effective treatment of hyperthyroidism, it spread worldwide. Also, its risk of developing malignancy or even the mortality risk were not significantly elevated [11]. However, it had disadvantages as worsening exophthalmos in Graves' disease patients with moderate or severe exophthalmos [12]. Also, it was advisable to be prevented in pregnant women for fear of its teratogenicity on the fetuses [1]. Besides, it could cause a sudden rise in thyroid hormones concentrations as a result of post radioiodine thyroiditis which increased the risk of cardiovascular disorders [1, 13]. Therefore, several adjunct therapies were used with RAI to increase its effectiveness, to prevent this acute increase of thyroid hormones, and to decrease its dose. One of these adjuncts was Lithium carbonate (LiCO3) [14].

Lithium salts were observed causing sedation in Guinea pigs, and LiCO3 in 1949 was introduced to patients with bipolar psychoses as a mode stabilizer [15]. The reason that lithium salts may be a suitable add-on with RAI is its significant inhibitory effect on the discharge rate of RAI from the gland [16], together with its ability to block the release of $\mathrm{TH}$ [17]. Lithium is also known to play a role in RAI retention in the gland being involved in blocking organic iodine and thyroid hormone release without effect on RAI uptake [18-20].
A cohort study in patients with Graves' disease confirmed the above mentioned theory and showed a higher cure rate in patients treated with RAI with LiCO3, as add-on therapy, after one year [20]. This higher cure rate suggests that using lithium, as an adjunct to RAI therapy, in thyrotoxicosis can be useful. However, there are discrepancies in outcomes of using $\mathrm{LiCO} 3$ as adjuvant therapy with I131 among published studies [14, 21, 22]. We aim to solve these differences by performing a systematic review and meta-analysis to determine the overall effect of adding lithium carbonate to RAI in the treatment of hyperthyroidism.

\section{Methods}

\section{Study design and registration}

We followed the Preferred Reporting Items for Systematic Reviews and Meta-Analyses (PRISMA) statement [23] to conduct this systematic review (SR) and metaanalysis (MA) for clinical trials whether randomized (RCT) or non-randomized. The study has no registered online protocol.

\section{Inclusion criteria}

We included studies that included patients with hyperthyroidism, Graves' disease, or toxic goiter, which uses LiCO3 with I131 as an intervention and RAI only as a comparative. The study design included clinical trials, whether randomized or non-randomized. Only Englishwritten human-based studies that provide published accessible full text were included.

\section{Primary outcomes}

The primary outcome of the study was the cure rate of the patients, which is the number of euthyroid or hypothyroid patients after the treatment period.

\section{Secondary outcomes}

The secondary outcome was the change in serum levels of total tetra-iodothyronine (T4) ( $\mathrm{ng} / \mathrm{ml})$.

\section{Search strategy and study selection}

We searched the PubMed, Scopus, Cochrane Central Register of Controlled Trials (CENTRAL) and Web of Science Core Collection databases from database inception through 27 July 2019. The search employed all relevant index terms and keywords and did not utilize any filters. The complete search strategy for all databases is available in the supplementary file.

The study selection process was done in two phases: title and abstract screening and full-text screening. Two independent investigators screened each item, and another investigator solved the conflict. 


\section{Data extraction}

We extracted the following data: the general features of the included studies, baseline characteristics, and outcomes of interest. General features included study design, country, timing, description of the intervention group, description of the control group, inclusion criteria, antithyroid drugs, duration of lithium administration, the reason for hyperthyroidism, and description of the intervention. Baseline characteristics included age (years), the onset of hyperthyroidism (months), gender (frequency), mean thyroid volume $(\mathrm{ml})$, and mean serum TSH (mIU/I). The extracted outcomes were serum's total T4 $(\mathrm{ng} / \mathrm{ml})$, and the number of euthyroid and hypothyroid patients (frequency).

\section{Dealing with missing data}

Some data were reported as mean and SE, so we used Revman 5.3 software to convert SE to SD. Besides, we calculated the mean difference for Serum total T4 outcome by subtracting the mean of baseline from that of Post-treatment value. In addition, we obtained the SD of the change from baseline using the method described by Foolman 1992 [24] and Abrams 2005 [25] for calculating the SD of the change from baseline using a decided on correlation coefficient. The correlation coefficient was decided to be zero as a conservative approach to yield the highest possible SD to avoid significant false results.

\section{Statistical analysis}

The extracted data regarding the cure rate was pooled as risk ratios, and the data about serum total T4 was pooled as mean differences. Both with the corresponding 95\% confidence intervals in a random-effects metaanalysis model using the Mantel-Haenszel equation. Student $\mathrm{T}$-test and Chi-square test were used to test the significant differences in the pooled data between the intervention and the control groups. We used Revman 5.3 software to perform the statistical analysis. We interpreted the results in forest plots for better visualization of data. We identified heterogeneity using the Chisquare heterogeneity test. We solved heterogeneity among studies by performing the leave-one-out sensitivity analysis. If the heterogeneity persisted, we used subgroup analysis. We used the random-effect model for heterogeneous data.

\section{Quality assessment}

For the randomized controlled trials, we used the Risk of Bias version 2 (ROB2) tool. We followed the Cochrane Handbook for Systematic Reviews of Interventions 5.1.0. in using the tool [26]. The tool consists of five domains that assess quality by answering signaling questions that help the authors determine the overall quality in each domain. The five domains include assessing the risk of bias in the randomization process, the risk of deviation from intended interventions, the risk of missing outcome data, the risk of bias in the measurement of the outcomes, and the risk in selecting the reported results. For the non-randomized trials, we used the ROBINS-1 tool [27]. The tool assessed the studies through signaling questions to determine the risk of bias in seven different domains. The tool included the same four domains as ROB-2 except for the randomization bias, in addition to three other domains regarding the confounding bias, selection bias, and bias in the classification of interventions. Funnel plot were used to assess the risk of bias across the studies.

\section{Results}

Data collection and study selection

Data collection retrieved 2003 results; 446 of them were duplicates and removed. The remaining 1557 studies were involved in the title and abstract screening phase. Only 108 studies were eligible for the inclusion criteria and entered the full text-screening phase. Nine studies were included in qualitative synthesis and quantitative synthesis (meta-analysis) [14, 21, 22, 28-33]. Six were randomized controlled trials $[14,21,22,28,29,31]$ and three were non-randomized controlled trials [30, 32, 33]. The study selection process was illustrated in Fig. 1.

The nine studies included 477 patients in the intervention group and 451 patients in the control group, with a total of 928 patients. The general features and the baseline characteristics of the nine included studies were organized in Tables 1 and 2, respectively.

\section{Quality assessment}

Regarding random sequence generation, only two studies-Lingudu et al. [21] and Thamcharoenvipas et al. [31]-reported an appropriate method of randomization. However, the rest of the studies were judged as unclear due to insufficient information. Allocation concealment risk was unclear for all of the included studies due to insufficient information except for the Hammond et al. study [29]. It was judged as high-risk potential because the investigators could intervene with the patients' assignment to the groups. The study of Thamcharoenvipas et al. [31] was judged as low-risk potential due to proper allocation concealment.

Regarding the blinding risk of bias, the Thamcharoenvipas et al. [31] study was a high-risk study concerning participants and personnel blinding because the physicians were not blinded. The study of Boggazzi et al., [14] was considered low-risk of bias regarding outcome assessors blinding because the examiners were sufficiently blinded. The rest of the included studies were considered as an unclear risk due to insufficient data. 


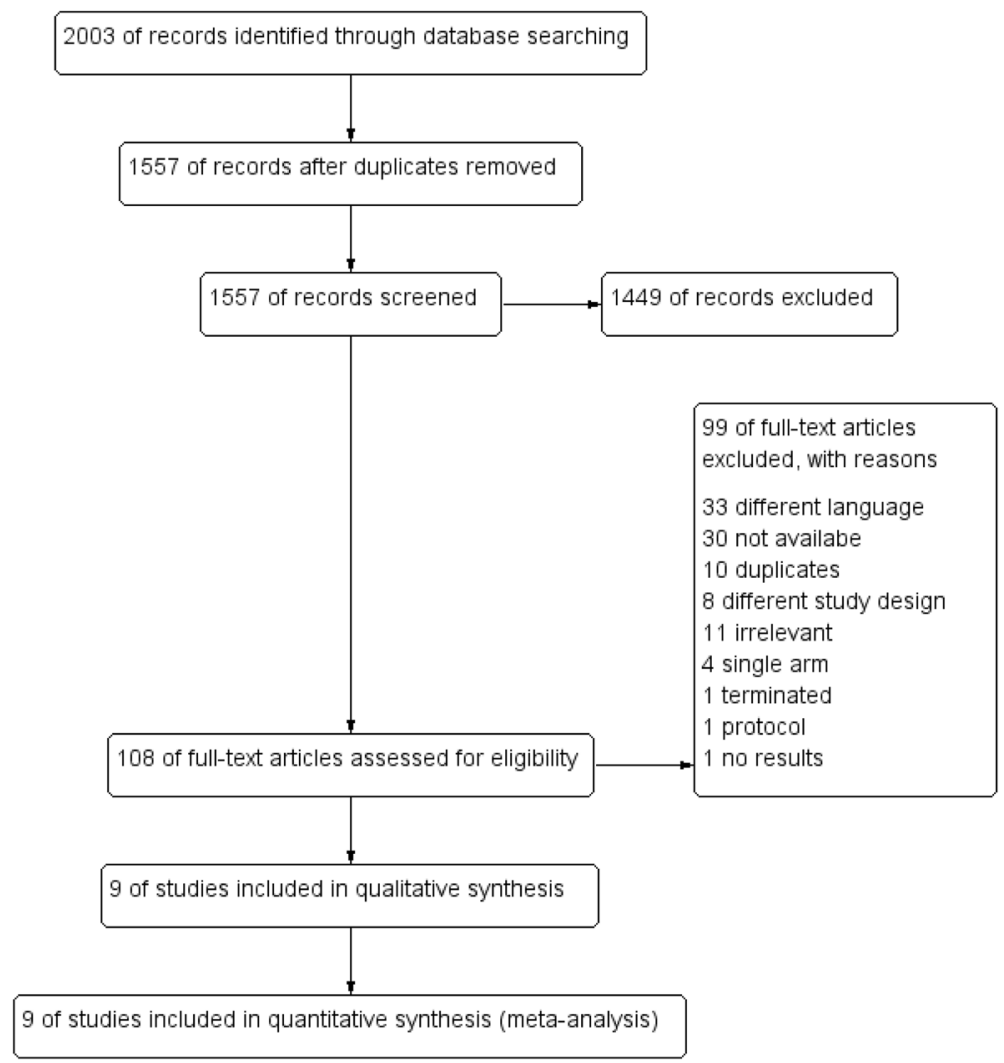

Fig. 1 Flow chart of the study selection process

Regarding the Incomplete outcome data bias, the studies of Bal et al. [22], Hammond et al. [29], and Boggazzi et al. 1998 [14] were considered as sources of high-risk bias due to their high patient attrition percentages (10, 12 , and $9 \%$, respectively), without any use of ITT method in the analysis of their data. The rest of the studies were judged as low risk.

For selective reporting, all studies were judged low risk except for the Hammond et al. [29] study. It was judged as high-risk potential due to incomplete reporting of the baseline characters of the patients' biochemical data. Moreover, all included studies were considered as highrisk potential in the domain of other bias due to the unavailability of the study protocols. All the included studies ranged from unclear to moderate concerning overall quality (Figs. 2 and 3).

On the other hand, of the nonrandomized trials, two (Oszukowska et al. 2010 and Sekulić et al. 2017 studies) were judged as low-risk, while one (Brownlie et al. 1979 study) was judged as high-risk bias [30, 34, 35].

Both Oszukowska et al. 2010 and Sekulić et al. 2017 had low-risk in most the ROBINS-I domains; however, Oszukowska et al. 2010 study had some variability in measuring outcomes among all included patients (bias in the measurement of outcomes). The study of
Brownlie et al. 1979 was considered high-risk because of lacking information in multiple domains including confounding and in the selection of participants into the study; moderate to high-risk were found among the domains of missing data, measurement of outcomes, and selection of the reported results (Table 3).

\section{Publication bias}

To assess the risk of bias across studies, a funnel plot was created for the main outcome. This analysis showed a significant risk of publication bias regarding the RCTs. On the other hand, the non-randomized controlled trials were nearly symmetrical in both sides of the middle line (Fig. 4).

\section{Primary outcomes}

The total number of patients being treated in the Intervention group is 477 with a cure rate of $84.7 \%$ (404 patients), while the number being treated in the control group is 451 patients with a cure rate of $78.5 \%$ (354 patients), (RR $=1.11,95 \% \mathrm{CI}, .96-1.28 ; P=.17)$, not favoring any of the two compared groups. Substantial heterogeneity was inspected among the pooled studies $\left(P=.0001, \mathrm{I}^{2}=75 \%\right)$ (Fig. 5). 
Table 1 Summary of the included studies

\begin{tabular}{|c|c|c|c|c|c|c|}
\hline Study ID & $\begin{array}{l}\text { Study } \\
\text { design, } \\
\text { country, } \\
\text { and timing }\end{array}$ & Criteria & $\begin{array}{l}\text { Intervention } \\
\text { group(s) }\end{array}$ & $\begin{array}{l}\text { Control } \\
\text { group }\end{array}$ & $\begin{array}{l}\text { Antithyroid } \\
\text { drugs }\end{array}$ & $\begin{array}{l}\text { Reason of } \\
\text { hyperthyroidism }\end{array}$ \\
\hline \multicolumn{7}{|c|}{ Randomized controlled trials } \\
\hline $\begin{array}{l}\text { Thamcharoenvipas } \\
\text { et al. } 2019\end{array}$ & $\begin{array}{l}\text { RCT, } \\
\text { Thailand, } \\
\text { between } \\
\text { April } 2015 \\
\text { and June } \\
2016\end{array}$ & $\begin{array}{l}\text { The inclusion criteria were } \\
\text { patients with thyroid gland } \\
\text { weight }>50 \mathrm{~g} \text { and age }>18 \\
\text { years }\end{array}$ & $\begin{array}{l}N=20 \\
3.7 \mathrm{MBq} / \mathrm{g} \text { thyroid } \\
\text { RAl plus } \mathbf{6 0 0} \mathbf{~ m g /} \\
\text { day } \mathrm{LiCO} 3 \text { for seven } \\
\text { days } \\
\mathrm{N}=20 \\
5.55 \mathrm{MBq} / \mathrm{g} \text { RAl plus } \\
\mathbf{6 0 0} \mathbf{~} \mathbf{~ g} / \text { day LiCO3 } \\
\text { for } 7 \text { days }\end{array}$ & $\begin{array}{l}\mathrm{N}=20 \\
7.4 \mathrm{MBq} / \mathrm{g} \\
\text { thyroid RAl } \\
\text { without } \\
\text { LiCO3 }\end{array}$ & $\begin{array}{l}\text { Propylthiouracil or } \\
\text { Methimazole. } \\
\text { (Stopped seven } \\
\text { days before } \\
\text { treatment) }\end{array}$ & Graves' disease \\
\hline $\begin{array}{l}\text { Hammond et al. } \\
2016\end{array}$ & $\begin{array}{l}\text { RCT, } \\
\text { South Africa, } \\
\text { between } \\
\text { February } \\
2014 \text { and } \\
\text { September } \\
2015\end{array}$ & $\begin{array}{l}\text { The inclusion criteria were } \\
\text { patients with hyperthyroidism } \\
\text { who have Graves' disease or } \\
\text { Plummer's disease }\end{array}$ & $\begin{array}{l}N=88 \\
\text { RAl plus lithium } \\
\mathbf{8 0 0} \mathbf{~} \mathbf{m g} / \text { day for } \\
\text { seven days }\end{array}$ & $\begin{array}{l}N=75 \\
\text { RAl alone }\end{array}$ & $\begin{array}{l}\text { Neomercazole, in } \\
\text { some patients. } \\
\text { (Stopped at least } \\
5-7 \text { days before } \\
\text { treatment) }\end{array}$ & $\begin{array}{l}\text { Graves' disease or } \\
\text { Plummer's disease } \\
\text { (toxic multinodular } \\
\text { goiter and toxic } \\
\text { adenoma) }\end{array}$ \\
\hline Lingudu et al. 2014 & $\begin{array}{l}\text { RCT, } \\
\text { India, } \\
\text { from } \\
\text { February } \\
2011 \text { to } \\
\text { January } \\
2012\end{array}$ & $\begin{array}{l}\text { Inclusion criteria were patients } \\
\text { with hyperthyroidism aged }> \\
18 \text { years, with mild or absent } \\
\text { Graves' ophthalmopathy }\end{array}$ & $\begin{array}{l}\mathrm{N}=20 \\
\mathrm{RAl} \text { plus lithium } \\
\mathbf{9 0 0} \mathbf{~} \mathbf{m g} / \text { day in } \\
\text { three divided doses } \\
\text { for six days }\end{array}$ & $\begin{array}{l}\mathrm{N}=20 \\
\mathrm{RAl} \text { alone }\end{array}$ & $\begin{array}{l}\text { Stopped seven } \\
\text { days before RAI }\end{array}$ & Graves' disease \\
\hline Bal et al. 2002 & $\begin{array}{l}\text { RCT, } \\
\text { India, } \\
\text { from Dec } \\
1994 \text { to } \\
\text { Dec. } 1999\end{array}$ & $\begin{array}{l}\text { Exclusion criteria were patients } \\
\text { with severe Graves' } \\
\text { ophthalmopathy, previous } \\
\text { treatment of hyperthyroidism } \\
\text { with radioiodine or surgery, } \\
\text { and those with } \\
\text { contraindications to lithium } \\
\text { treatment }\end{array}$ & $\begin{array}{l}N=164 \\
\text { Radioactive iodine } \\
\text { plus lithium } \\
\text { carbonate } \mathbf{9 0 0} \mathbf{~ m g /} \\
\text { day for three weeks }\end{array}$ & $\begin{array}{l}N=152 \\
\text { Radioactive } \\
\text { iodine with } \\
\text { no lithium }\end{array}$ & $\begin{array}{l}\text { carbimazole } \\
\text { (stopped } 3-4 \text { days } \\
\text { before the } \\
\text { radioiodine } \\
\text { therapy) }\end{array}$ & $\begin{array}{l}\text { Graves' disease, } \\
\text { autonomous } \\
\text { functioning thyroid } \\
\text { nodule (AFTN), or a } \\
\text { toxic multinodular } \\
\text { goiter (TMNG) }\end{array}$ \\
\hline Bogazzi et al. 2002 & $\begin{array}{l}\text { RCT, } \\
\text { Italy, } \\
\text { During the } \\
\text { year 1999- } \\
2000\end{array}$ & $\begin{array}{l}\text { Inclusion criteria were patients } \\
\text { with hyperthyroidism (Graves' } \\
\text { disease), aged }>20 \text { years }\end{array}$ & $\begin{array}{l}N=12 \\
\text { RAl plus lithium } \\
\mathbf{9 0 0} \mathbf{~ m g / d} \text { for } 6 \\
\text { days } \\
N=12 \\
\text { RAl plus lithium } \\
\mathbf{9 0 0} \mathbf{~ m g / d ~ f o r ~} 19 \\
\text { days }\end{array}$ & $\begin{array}{l}\mathrm{N}=12 \\
\mathrm{RAl} \text { only }\end{array}$ & $\begin{array}{l}\text { Methimazole } \\
\text { (Stopped five days } \\
\text { before RAl } \\
\text { therapy) }\end{array}$ & Graves' disease \\
\hline Bogazzi et al. 1999 & $\begin{array}{l}\text { RCT, } \\
\text { Italy, } \\
\text { During the } \\
\text { period } \\
\text { 1994-1996 }\end{array}$ & $\begin{array}{l}\text { Inclusion criteria were patients } \\
\text { with hyperthyroidism (Graves' } \\
\text { disease), aged }>20 \text { years }\end{array}$ & $\begin{array}{l}N=54 \\
\text { RAl plus lithium } \\
\mathbf{9 0 0} \mathbf{~ m g / d a y ~ f o r ~} 6 \\
\text { days }\end{array}$ & $\begin{array}{l}N=46 \\
\text { RAl only }\end{array}$ & $\begin{array}{l}\text { Methimazole } \\
\text { (stopped five days } \\
\text { before RAl } \\
\text { therapy) }\end{array}$ & Graves' disease \\
\hline \multicolumn{7}{|c|}{ Non-Randomized controlled trials. } \\
\hline Sekulić et al. 2017 & $\begin{array}{l}\text { Non-RCT, } \\
\text { Serbia, } \\
\text { from April } \\
2012 \text { to } \\
\text { March } 2016\end{array}$ & $\begin{array}{l}\text { The inclusion criteria were } \\
\text { patients aged } 20-70 \text { years, with } \\
\text { the gland size estimated by } \\
\text { palpation as a grade } 0 \\
\text { (normal-sized, invisible), grade } \\
1 \text { (slightly enlarged, visible), } \\
\text { and grade } 2 \text { (moderately } \\
\text { enlarged, highly visible) }\end{array}$ & $\begin{array}{l}\mathrm{N}=30 \\
131 / \text { and } \mathrm{LiCO} 3 \mathbf{9 0 0} \\
\mathbf{m g} \mathbf{\text { day }} \text { for seven } \\
\text { days }\end{array}$ & $\begin{array}{l}N=30 \\
131 \mid \text { alone }\end{array}$ & $\begin{array}{l}\text { Stopped seven } \\
\text { days before RAl }\end{array}$ & $\begin{array}{l}\text { Patients with } \\
\text { recurrent and long- } \\
\text { lasting Grave's } \\
\text { hyperthyroidism }\end{array}$ \\
\hline $\begin{array}{l}\text { Oszukowska et al. } \\
2010\end{array}$ & $\begin{array}{l}\text { Non-RCT, } \\
\text { Poland, } \\
2010 .\end{array}$ & $\begin{array}{l}\text { The reported retrospective } \\
\text { study involved } 200 \text { patients } \\
\text { with hyperthyroidism, treated } \\
\text { with radioactive iodine }\end{array}$ & $\begin{array}{l}\mathrm{N}=40 \\
\text { Radioiodine therapy } \\
\text { plus lithium } \\
\text { carbonate } \mathbf{7 5 0} \mathbf{~ m g /} \\
\text { day for ten days }\end{array}$ & $\begin{array}{l}N=40 \\
\text { Radioiodine } \\
\text { only }\end{array}$ & Not reported & $\begin{array}{l}\text { Graves' disease or } \\
\text { toxic nodular goiter }\end{array}$ \\
\hline TURNER et al. 1976 & Non-RCT & Inclusion criteria were patients & $N=16$ & $N=16$ & Carbimazole or & Diffuse thyroid \\
\hline
\end{tabular}


Table 1 Summary of the included studies (Continued)

\begin{tabular}{|c|c|c|c|c|c|c|}
\hline Study ID & $\begin{array}{l}\text { Study } \\
\text { design, } \\
\text { country, } \\
\text { and timing }\end{array}$ & Criteria & $\begin{array}{l}\text { Intervention } \\
\text { group(s) }\end{array}$ & $\begin{array}{l}\text { Control } \\
\text { group }\end{array}$ & $\begin{array}{l}\text { Antithyroid } \\
\text { drugs }\end{array}$ & $\begin{array}{l}\text { Reason of } \\
\text { hyperthyroidism }\end{array}$ \\
\hline & $\begin{array}{l}\text { New } \\
\text { Zealand, } \\
1976\end{array}$ & $\begin{array}{l}\text { with Diffuse thyroid } \\
\text { hyperplasia as assessed by } \\
\text { thyroid scan. }\end{array}$ & $\begin{array}{l}1311 \text { ( } 5 \text { mCi) and } \\
\text { lithium carbonate } \\
\mathbf{4 0 0} \mathbf{~} \mathbf{g} \text { daily for } \\
\text { one week before } \\
\text { and one week after } \\
1311\end{array}$ & $\begin{array}{l}131 \text { I }(5 \mathrm{mCi}) \\
\text { without } \\
\text { lithium } \\
\text { therapy }\end{array}$ & $\begin{array}{l}\text { propylthiouracil; } \\
\text { (stopped one } \\
\text { week prior to the } \\
\text { start of the } \\
\text { radioiodine) }\end{array}$ & hyperplasia \\
\hline
\end{tabular}

RCT: Randomized controlled trial. N: number. RAl: radioactive iodine therapy. MBg: megabecquerel. mCi: millicurie

Table 2 Baseline characters of the patients in the included studies

\begin{tabular}{|c|c|c|c|c|c|c|}
\hline Study ID & $\begin{array}{l}\text { Study } \\
\text { groups }\end{array}$ & $\begin{array}{l}\text { Age } \\
\text { (years) } \\
\text { Mean } \\
\text { (SD) }\end{array}$ & $\begin{array}{l}\text { Gender (males) } \\
\text { Number, } \\
\text { percentage }\end{array}$ & $\begin{array}{l}\text { The onset of } \\
\text { hyperthyroidism (years) } \\
\text { Mean (SD) }\end{array}$ & $\begin{array}{l}\text { Mean thyroid } \\
\text { volume }(\mathrm{ml}) \\
\text { Mean }(\mathrm{SD})\end{array}$ & $\begin{array}{l}\text { Mean serum TSH } \\
(\mathrm{mIU} / \mathrm{l}) \\
\text { Mean (SD) }\end{array}$ \\
\hline \multicolumn{7}{|c|}{ Randomized controlled trials } \\
\hline \multirow[t]{3}{*}{$\begin{array}{l}\text { Thamcharoenvipas } \\
\text { et al } 2019\end{array}$} & $\begin{array}{l}\text { Intervention } \\
1\end{array}$ & $30(7.4)$ & $3,15 \%$ & $21.3(32.6)$ & $82.6(30.4)$ & $.005(.006)$ \\
\hline & $\begin{array}{l}\text { Intervention } \\
2\end{array}$ & $34.3(13)$ & $1,5 \%$ & $30.3(39.3)$ & $87.1(21.0)$ & $.011(.02)$ \\
\hline & control & $\begin{array}{l}31.8 \\
(12.2)\end{array}$ & $8,40 \%$ & $15.2(19.6)$ & $98.9(36.0)$ & $.003(.004)$ \\
\hline \multirow[t]{2}{*}{ Hammond et al. 2016} & intervention & $\begin{array}{l}43.7 \\
(13.2)\end{array}$ & $9,10 \%$ & NA & NA & .05 \\
\hline & control & $\begin{array}{l}48.4 \\
(12.0)\end{array}$ & $11,14.7 \%$ & NA & NA & .04 \\
\hline \multirow[t]{2}{*}{ Lingudu et al. 2014} & intervention & $35.9(7.5)$ & $2,10 \%$ & $19.7(21)$ & $26.7(15.8)$ & NA \\
\hline & control & $\begin{array}{l}37.3 \\
(12.7)\end{array}$ & $9,45 \%$ & $15.5(10.8)$ & $28.2(12.4)$ & NA \\
\hline \multirow[t]{2}{*}{ Bal et al. 2002} & intervention & $\begin{array}{l}41.8 \\
(12.2)\end{array}$ & $61,37.2 \%$ & $6.1(47.9)$ & $48(29.0)$ & NA \\
\hline & control & $\begin{array}{l}41.8 \\
(11.5)\end{array}$ & $54,35.5 \%$ & $45.4(41.6)$ & $45(24.0)$ & NA \\
\hline \multirow[t]{3}{*}{ Bogazzi et al. 2002} & $\begin{array}{l}\text { Intervention } \\
1\end{array}$ & $48.0(9.0)$ & $2,16.7 \%$ & $37.3(2.4)$ & $19(10)$ & $1.3(1.3)$ \\
\hline & $\begin{array}{l}\text { Intervention } \\
2\end{array}$ & $51.0(9.0)$ & $3,25 \%$ & $5.7(2.0)$ & $21(11.0)$ & $1.4(1.7)$ \\
\hline & control & $\begin{array}{l}52.0 \\
(13.0)\end{array}$ & $4,33.4 \%$ & $5.3(1.8)$ & $24(13.0)$ & $2.3(1.8)$ \\
\hline \multirow[t]{2}{*}{ Bogazzi et al. 1999} & Intervention & $45(12.8)$ & $10,18.5 \%$ & $6.1(2.3)$ & $38(22.0)$ & $.6(1.0)$ \\
\hline & Control & $51(15.8)$ & $9,16.7 \%$ & $5.7(2.3)$ & $35(21.0)$ & $.4(.9)$ \\
\hline \multicolumn{7}{|c|}{ Non-randomized controlled trials } \\
\hline \multirow[t]{2}{*}{ Sekulić et al 2017} & Intervention & $53.9(8.8)$ & $5,16.7 \%$ & $84.2(68.0)$ & NA & $.9(.6)$ \\
\hline & Control & $51.3(9.2)$ & $6,20 \%$ & $72.6(52.6)$ & NA & $.9(.88)$ \\
\hline \multirow[t]{2}{*}{ Oszukowska et al 2010} & Intervention & 52.1 & $29(14.5 \%)$ & NA & NA & NA \\
\hline & Control & $(13.1)$ & & NA & NA & NA \\
\hline \multirow[t]{2}{*}{ TURNER et al 1976} & Intervention & $44(10.3)$ & $5,31.3 \%$ & NA & NA & NA \\
\hline & Control & $43(7.8)$ & $2,12.5 \%$ & NA & NA & NA \\
\hline
\end{tabular}

Data is expressed as mean and standard deviation (SD) or frequency and percentage. NA: not availabe 


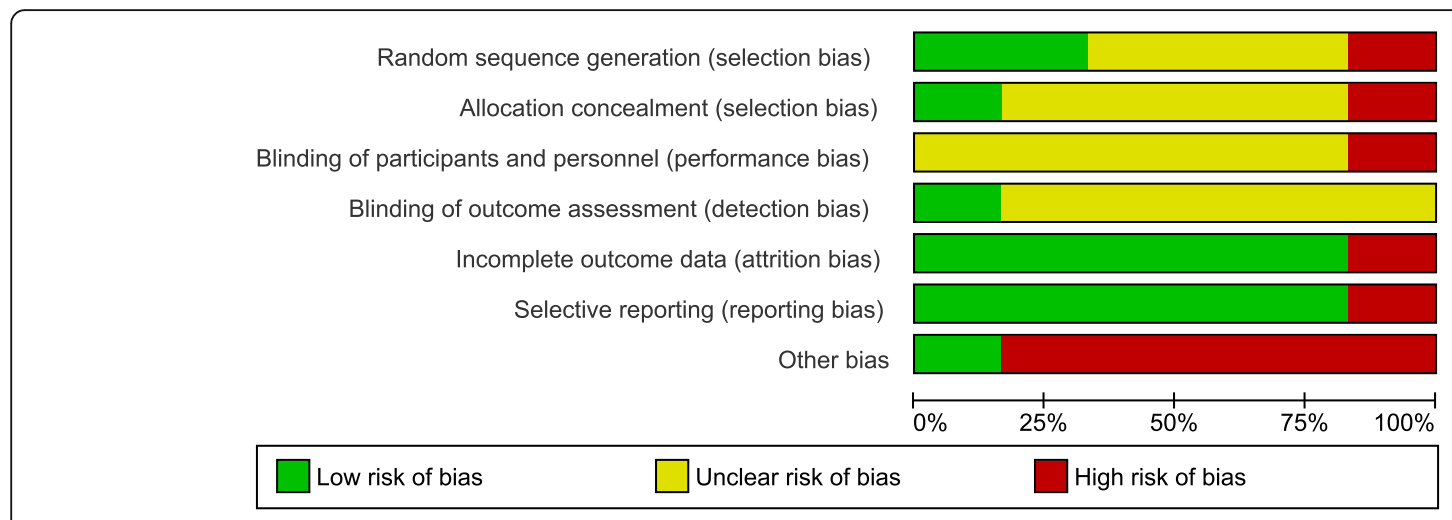

Fig. 2 Risk of bias graph for randomized controlled trials using ROB2

The pooled data from the RCTs alone (6 studies) as a sub-group did not favor any of the two groups with a cure rate of $85.4 \%$ in the intervention group and $80 \%$ in the control group ( $\mathrm{RR}=1.11,95 \% \mathrm{CI}, .89-1.39 ; P=.34$ ). Considerable heterogeneity was detected among the pooled studies $\left(P=.0001 ; \mathrm{I}^{2}=84 \%\right)$ (Fig. 5 ).

Pooling the data of the non-RCTs (3 studies) as a separate sub-group also did not favor any of the compared groups with a cure rate of $81.6 \%$ in the intervention group and $74.6 \%$ in the control group ( $\mathrm{RR}=1.09,95 \% \mathrm{CI}, .94-1.26 ; P=$ .25). The pooled studies were homogenous (Fig. 5).

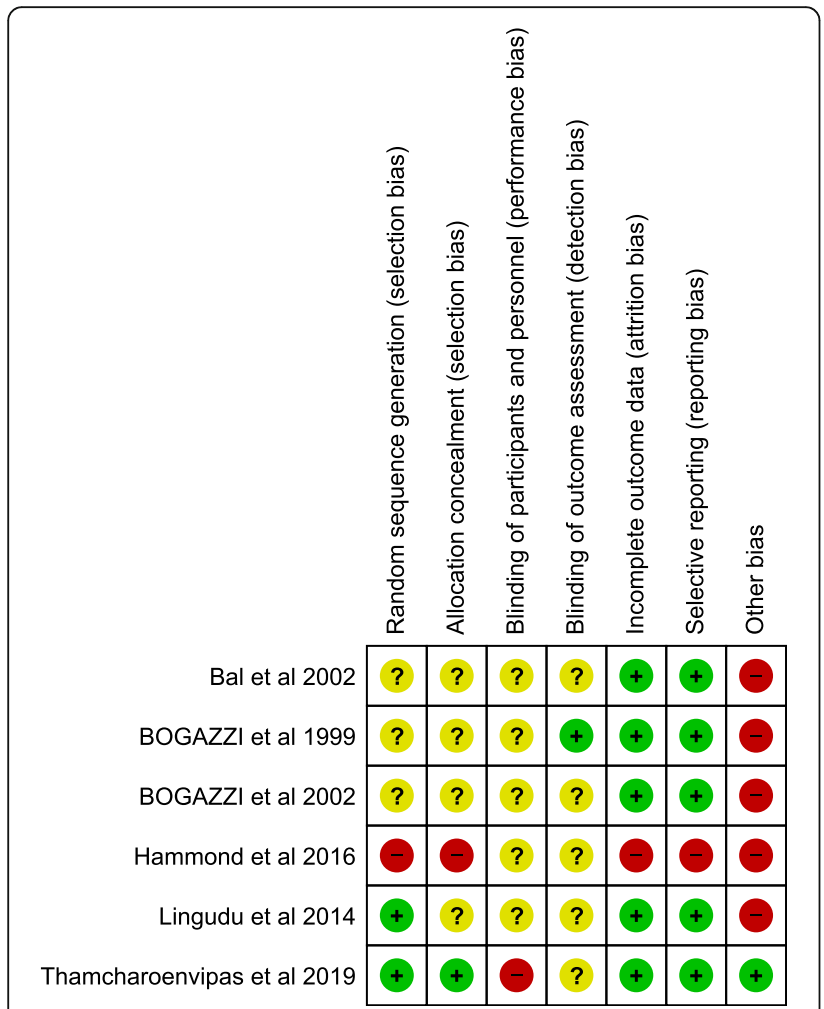

Fig. 3 Risk of bias summary for randomized controlled trials using ROB2

\section{Analysis of the studies according to the total dose}

The overall cure rate of LiCO3 (optimized dose: 5000 to $6500 \mathrm{mg}$ ) significantly favored the Intervention (LiCO3) group over the control group-with the exclusion of extremely low [31] or extremely high [22,33] doses of the study groups. The pooled results showed a cure rate of $83.7 \%$ in the intervention (221 patients) versus $66.3 \%$ in the control group (199 patients) $(\mathrm{RR}=1.27,95 \% \mathrm{CI}$, $1.13-1.42 ; \quad P=.0001)$. The pooled studies were homogenous $\left(P=.76, \mathrm{I}^{2}=0 \%\right)$ (Fig. 6).

\section{Secondary outcomes}

The effect of the intervention on serum total T4 of the patients was reported in three studies (120 patients). The overall pooled result did not favor either of the two groups (SMD $=-24.26,95 \% \mathrm{CI},-0.6-0.12 ; P=.18)$. The pooled studies were homogenous $\left(P=.82, \mathrm{I}^{2}=0 \%\right)$ (Fig. 7).

\section{Discussion}

This systematic review and meta-analysis study is based on nine clinical trials, including 928 patients with hyperthyroidism; 715 of them were randomly selected to RAI with lithium carbonate or RAI only. The rest of the studies were non-randomized. Our meta-analysis showed that the overall effect of LiCO3-5000 to $6500 \mathrm{mg}$ for six or seven days-plus RAI led to better cure rates among hyperthyroidism patients than in the control group ( $R R=$ $1.24,95 \% \mathrm{CI}, 1.11-1.39)$. This result depends on the analysis of 420 patients in six trials [14, 21, 28-30, 32]. Conversely, the last meta-analysis reported non-significant differences in the cure rate between two groups of four randomized trials, including Bal et al., [22].

When we sub-grouped the included studies regarding their randomization, we noted that there was no significant difference regarding the cure rate between the intervention group and the control group of both randomized and non-randomized studies. These nonsignificant results may be due to the presence of trials with extremities in doses and durations. For instance, 
Table 3 Quality assessment of the nonrandomized trials using ROBINS-I

\begin{tabular}{|c|c|c|c|}
\hline $\begin{array}{l}\text { Study } \\
\text { Domain } \\
\end{array}$ & Oszukowska et al. 2010 & Sekulić et al. 2017 & Brownlie et al. 1979 \\
\hline \multicolumn{4}{|l|}{ Pre-intervention } \\
\hline Bias due to confounding & Probably No & Probably No & No Information \\
\hline Bias in selection of participants into the study & Probably No & No & No Information \\
\hline \multicolumn{4}{|l|}{ At intervention } \\
\hline Bias in classification of interventions & No & No & No \\
\hline \multicolumn{4}{|l|}{ Post-intervention } \\
\hline Bias due to deviations from intended interventions & No & No & No \\
\hline Bias due to missing data & No Information & No Information & Probably Yes \\
\hline Bias in measurement of outcomes & Probably Yes & No & Probably No \\
\hline Bias in selection of the reported result & No & No & Probably Yes \\
\hline Overall risk of bias & Low risk bias & Low risk of bias & High risk of bias \\
\hline
\end{tabular}

Oszukowska et al. [33] is a non-randomized trial in which the cumulative dose was $7500 \mathrm{mg}$ for ten days. Moreover, Bal et al., [22] and Thamcharoenvipas et al., [31] are randomized trials in which the doses were 18, $600 \mathrm{mg}$ for 21 days and $4200 \mathrm{mg}$ for seven days, respectively.

LiCO3 is administrated orally, totally absorbed, not metabolized, excreted unchanged by the renal system, and has a 12-h half-life. All of the dose is distributed through the body fluid, interstitial fluid, and eventually, slowly enters the cells [36]. RAI worsened the cure rate status in participants with a large thyroid gland, quick iodine washout, and diminished iodine uptake [37]. Lithium increased the half-life of RAI [16] and prevented the discharge of $\mathrm{TH}$ [17]. However, Thamcharoenvipas et al. [31] reported LiCO3 was harmful in rapid turnover Graves' disease. This might be due to the whole dose of LiCO3 being 18,600 mg for three weeks which is considered as a high dose. Moreover, using LiCO3 with 3.7 $\mathrm{mBq} / \mathrm{g}$ of RAI for Graves' cases with rapid turnover uptake was a standard of use at their institution.

Regarding the secondary outcome, three studies disclosed decreased serum T4 without meaningful statistical variation between both the $\mathrm{LiCO} 3$ group and the

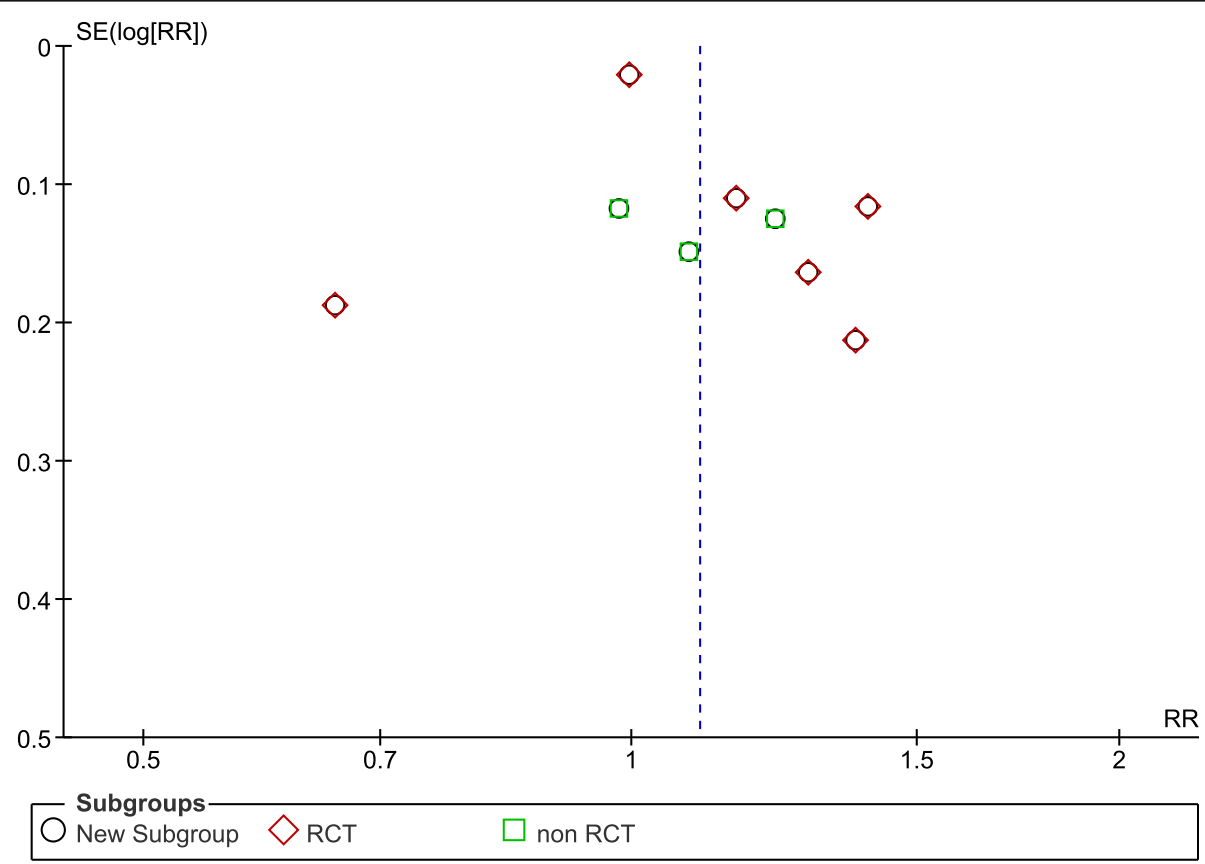

Fig. 4 Funnel plot showing the risk of bias across the included studies 


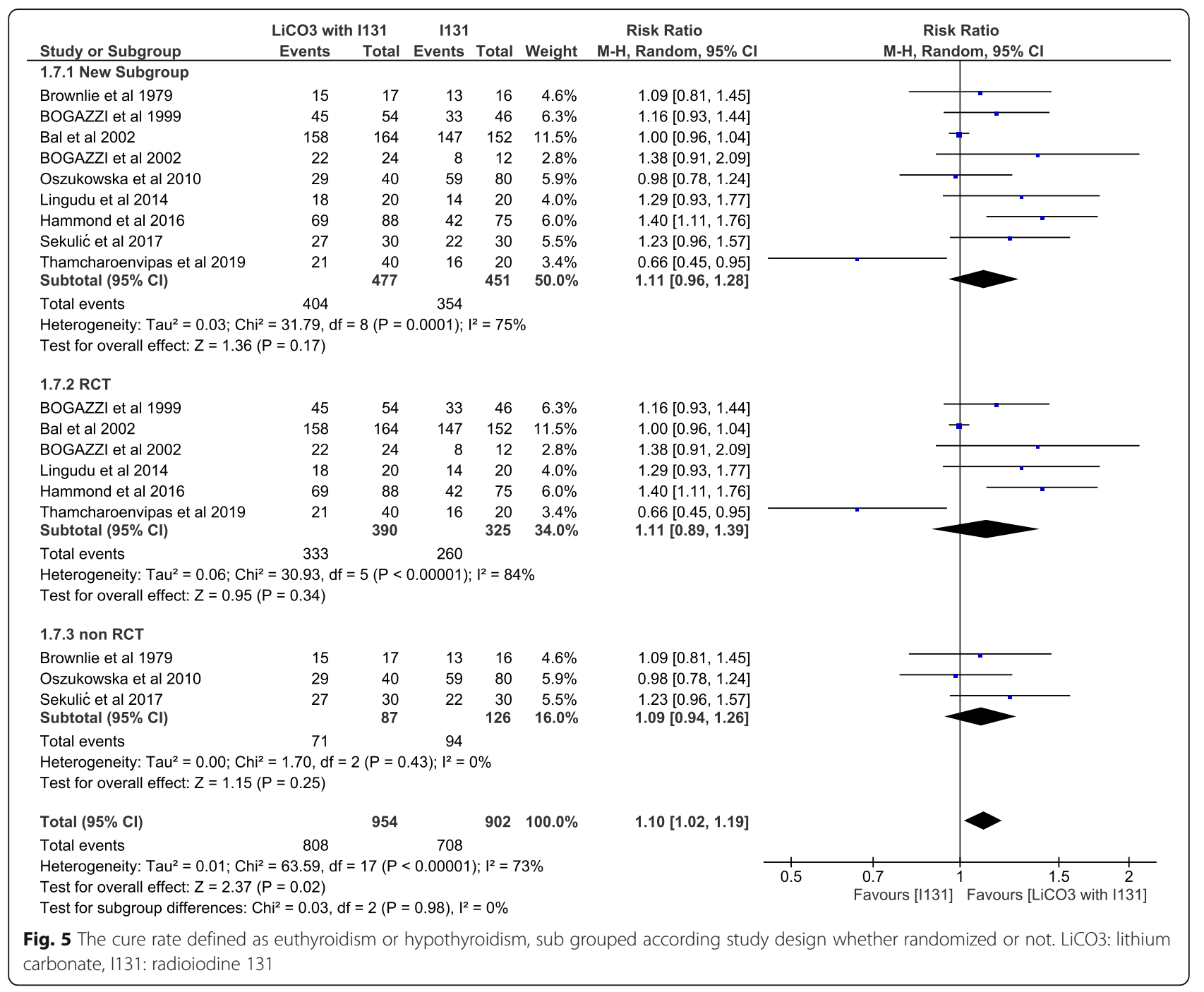

control group. Sekulic et al. [30] showed an increase in T4 level and a decrease of TSH level for seven days in patients treated with RAI only. This reflex resulted from gland irradiation, while this phenomenon was lost in the LiCO3 group. Lingudu et al. [21] explicated that at four months, the group treated with RAI had undergone an abrupt drop of T4 and T3 levels. Of note, this rapid control may be helpful in elderly and cardiac patients.

The quality of the current evidence was considered good due to rigorous adherence to the Cochrane






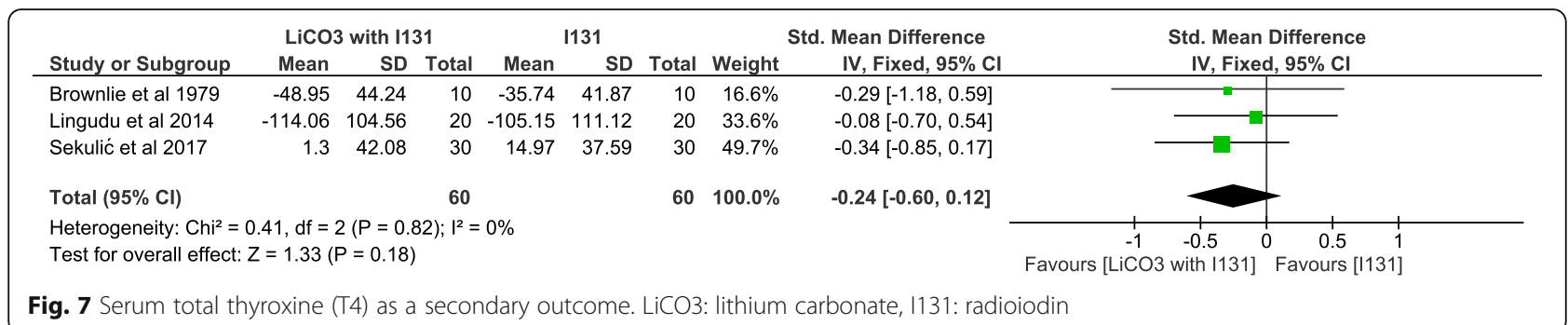

Handbook about systematic reviews and the PRISMA checklist in all the steps performed. Furthermore, we included nine trials in nine; six of them were randomized.

The strengths of our study can be summarized as we included only clinical trials that considered first-class evidence and applied multiple scales to appraise the same result. We did subgroup analysis according to randomization. In studies that did not report the correlation coefficient, we assumed it is zero as a conservative approach to yield the highest standard deviation and to avoid significant false results.

The limitations were that we included trials published in the English language only. We obtained the outcome data of Turner et al. from Brownlie et al. [32, 38]. Only nine controlled trials with different $\mathrm{LiCO} 3$ dosage regimens (six randomized and three non-randomized) matched our criteria of inclusion, six of them only included the preferred dosage. The most frequent dose used among studies exhibited significant results. In addition, the bias assessment of individual studies revealed an unclear risk of bias for several important domains, which indicates that a high degree of bias within these studies is possible. The risk of bias across studies revealed an asymmetrical publication pattern, indicating a potential bias in the body of literature. Taken together these indications warrant caution in the interpretation of the results. Further studies are needed to confirm these finding.

\section{Conclusion}

This study suggests that the use of $\mathrm{LiCO} 3$ with a cumulative dose of 5000 to $6500 \mathrm{mg}$ for approximately seven days, as adjuvant therapy to RAI, may be effective in hyperthyroid conditions, while the extremities doses of lithium may not be beneficial.

\section{Supplementary Information}

The online version contains supplementary material available at https://doi. org/10.1186/s12902-021-00729-2.

Additional file 1.

Code availability

Not applicable.
Authors' contributions

Mohamed Abd-ElGawad leads the team, performed the search strategy and data collection step, solved any conflict in the screening phase, performed the meta-analysis part, and solved any conflict in the quality assessment part, took part in the data extraction phase. Mohamed Abdelmonem took part in the screening process, Data extraction, and reviewed the meta-analysis. Ahmed Eissa Ahmed took part in the screening process, the quality assessment, and writing the manuscript. Omar Magdy Mohammed took part in the screening process and quality assessment. Mohamed Sayed Zaazouee, Ahmed Assar, Mohamed Gadelkarim wrote the manuscript. Ahmed Afifi supervised the authors in all steps and performed peer-review. All authors reviewed the manuscript. The authors read and approved the final manuscript.

\section{Funding}

$20.0 \%$ waiver for the APC of your manuscript from springer nature waivers team

\section{Availability of data and materials}

All data generated or analyzed during this study are included in this published article or in the data repositories listed in References.

\section{Declarations}

Consent to participate

Not applicable.

\section{Ethics approval}

Not applicable.

\section{Consent for publication}

Not applicable.

\section{Competing interests}

Dr. Abd-ElGawad has nothing to disclose. All the authors also declare no conflict of interest.

\section{Author details}

${ }^{1}$ Faculty of Medicine, Fayoum University, 5 Al-Touba Street, from Al-Fanya Street, Al-Hadka road, Fayoum, Fayoum, Egypt. 'Faculty of Medicine, Al-Azhar University, Assiut, Egypt. ${ }^{3}$ Faculty of Medicine, Menofia University, Shebin El-Kom, Menofia, Egypt. ${ }^{4}$ Faculty of Medicine, Alexandria University, Alexandria, Egypt. ${ }^{5}$ Department of Internal Medicine and Division of Digestive Diseases, College of Medicine, University of Kentucky, Lexington, USA.

Received: 21 October 2020 Accepted: 26 March 2021

Published online: 12 April 2021

References

1. Cooper DS. Hyperthyroidism. Lancet. 2003;362(9382):459-68. https://doi. org/10.1016/S0140-6736(03)14073-1.

2. Antonelli A, Ferrari SM, Corrado A, Di Domenicantonio A, Fallahi P. Autoimmune thyroid disorders. Autoimmun Rev. 2015;14(2):174-80. https:// doi.org/10.1016/j.autrev.2014.10.016.

3. Menconi F, Marcocci C, Marinò M. Diagnosis and classification of Graves' disease. Autoimmun Rev. 2014;13(4-5):398-402. https://doi.org/10.1016/j.a utrev.2014.01.013. 
4. Burch HB, Cooper DS. Management of Graves Disease. Jama. 2015;314(23): 2544. https://doi.org/10.1001/jama.2015.16535.

5. van Noord C, Sturkenboom MC, Straus SM, Hofman A, Witteman JC, Stricker BH. Population-based studies of antithyroid drugs and sudden cardiac death. Br J Clin Pharmacol. 2009;68(3):447-54. https://doi.org/10.1111/j.13 65-2125.2009.03474.x.

6. Franklyn JA. The management of hyperthyroidism. N Engl J Med. 1994; 25(331):559.

7. Liu J, Jing F, Xu Y, Wang G. Antithyroid drug therapy for graves' disease and implications for recurrence. Int J Endocrinol. 2017;2017:1-8.

8. Stokkel MPM, Junak DH, Lassmann M, Dietlein M, Luster M. EANM procedure guidelines for therapy of benign thyroid disease. Eur J Nucl Med Mol Imaging. 2010;37:2218-28.

9. Becker DV, Sawin CT. Radioiodine and thyroid disease: the beginning. Semin Nucl Med. 1996;26(3):155-64.

10. Sawin $C T$, Becker DV. Radioiodine and the treatment of hyperthyroidism: the early history. Thyroid. 1997;7(2):163-76.

11. Ron E, Doody MM, Becker DV, et al. Cancer Mortality Following Treatment for Adult Hyperthyroidism. JAMA. 1998;280(4):347-55. https://doi.org/10.1 001/jama.280.4.347

12. Bartalena L, Marcocci C, Bogazzi F, Manetti L, Tanda ML, Dell'Unto E, BrunoBossio G, Nardi M, Bartolomei MP, Lepri A, Rossi G, Martino E, Pinchera A. Relation between therapy for hyperthyroidism and the course of Graves' ophthalmopathy. N Engl J Med. 1998;338(2):73-8. https://doi.org/10.1056/ NEJM199801083380201. PMID: 9420337.

13. Shafer RB, Nuttall FQ. Acute changes in thyroid function in patients treated with radioactive iodine. Lancet. 1975;2(7936):635-7. https://doi.org/10.1016/ s0140-6736(75)90117-8. PMID: 52005.

14. Bogazzi F, Bartalena L, Brogioni S, Scarcello G, Burelli A, Campomori A, et al. Comparison of radioiodine with radioiodine plus Lithium in the treatment of graves' hyperthyroidism. J Clin Endocrinol Metab. 1999;84(2):499-503. https://doi.org/10.1210/jcem.84.2.5446.

15. Schou M, Juel-Nielsen N, Stromgren E, Voldby H. The treatment of manic psychoses by the administration of lithium salts. J Neurol Neurosurg Psychiatry. 1954;17(4):250-60. https://doi.org/10.1136/jnnp.17.4.250.

16. Burrow GN, Burke WR, Himmelhoch JM, Spencer RP, Hershman JM. Effect of Lithium on thyroid function. J Clin Endocrinol Metab. 1971;32(5):647-52. https://doi.org/10.1210/jcem-32-5-647.

17. Spaulding SW, Burrow GN, Bermudez F, Himmelhoch JM. The inhibitory effect of Lithium on thyroid hormone release in both Euthyroid and Thyrotoxic patients. J Clin Endocrinol Metab. 1972;35(6):905-11. https://doi. org/10.1210/jcem-35-6-905.

18. Bogazzi F, Bartalena L, Brogioni S, Scarcello G, Burelli A, Campomori A, et al. Comparison of radioiodine with radioiodine plus Lithium in the treatment of graves' Hyperthyroidism1. J Clin Endocrinol Metab. 1999;84(2):499-503.

19. Atmaca A, Dogan S, Dagdelen S, Gurlek A, Bayraktar M, Adalar N. Symptomatic Treatment of Graves Hyperthyroidism With Lithium in States of Thionamide Adverse Reactions: A Retrospective Analysis. The Endocrinol. 2004;14(6).

20. Bogazzi F, Giovannetti C, Fessehatsion R, Tanda ML, Campomori A, Compri E, et al. Impact of Lithium on efficacy of radioactive iodine therapy for graves' disease: a cohort study on cure rate, time to cure, and frequency of increased serum Thyroxine after Antithyroid drug withdrawal. J Clin Endocrinol Metab. 2010;95(1):201-8. https://doi.org/10.1210/jc.2009-1655.

21. Lingudu B, Bongi V, Ayyagari M, Venkata SK. Impact of lithium on radioactive iodine therapy for hyperthyroidism. Indian J Endocrinol Metab. 2014;18(5):669-75. https://doi.org/10.4103/2230-8210.139230.

22. Bal C, Kumar A, Pandey RM. A randomized controlled trial to evaluate the adjuvant effect of Lithium on radioiodine treatment of hyperthyroidism. Thyroid. 2002;12(5):399-405. https://doi.org/10.1089/105072502760043486.

23. Moher D, Liberati A, Tetzlaff J, Altman DG, Group P. Preferred reporting items for systematic reviews and meta-analyses: the PRISMA statement. PLoS Med. 2009;6(7):e1000097-e.

24. Follmann DEP, Suh I, Cutler J. Variance imputation for overviews of clinical trials with continuous response. J Clin Epidemiol. 1992;45(7):769-73. https:// doi.org/10.1016/0895-4356(92)90054-Q.

25. Abrams KR, Gillies CL, Lambert PC. Meta-analysis of heterogeneously reported trials assessing change from baseline. Stat Med. 2005;24(24):382344. https://doi.org/10.1002/sim.2423.

26. AD HJPT, JAC S. Chapter 8: assessing risk of bias in included studies. In: JPT $\mathrm{H}$, Green S, editors. Cochrane handbook for systematic reviews of interventions version 5.1.0 (updated March 2011): The Cochrane Collaboration; 2011.

27. Sterne JA, Hernán MA, Reeves BC, Savović J, Berkman ND, Viswanathan M, et al. ROBINS-I: a tool for assessing risk of bias in non-randomised studies of interventions. BMJ (Clinical research ed). 2016;355:i4919.

28. Bogazzi F, Bartalena L, Campomori A, Brogioni S, Traino C, De Martino F, et al. Treatment with lithium prevents serum thyroid hormone increase after thionamide withdrawal and radioiodine therapy in patients with Graves' disease. J Clin Endocrinol Metab. 2002;87(10):4490-5. https://doi. org/10.1210/jc.2002-020580.

29. Hammond ENB, Vangu M-D-THW. Lithium-enhanced radioactive iodine ablation of hyperthyroid patients. J Endocrinol Metab Diabetes S Afr. 2016; 21(3):51-5. https://doi.org/10.1080/16089677.2016.1228745.

30. Sekulic V, Rajic M, Vlajkovic M, llic S, Stevic M, Kojic M. The effect of shortterm treatment with lithium carbonate on the outcome of radioiodine therapy in patients with long-lasting Graves' hyperthyroidism. Ann Nucl Med. 2017;31(10):744-51. https://doi.org/10.1007/s12149-017-1206-z.

31. Thamcharoenvipas S, Kerr SJ, Tepmongkol S. Finding the best effective way of treatment for rapid I-131 turnover Graves' disease patients: a randomized clinical trial. Medicine (Baltimore). 2019;98(19):e15573. https://doi.org/10.1 097/MD.0000000000015573.

32. JGT BEWB, Ovenden BM, Rogers TGH. Results of lithium-1311 treatment of thyrotoxicosis. J Endocrinol Invest. 1979;2(303).

33. Oszukowska L, Knapska-Kucharska M, Makarewicz J, Lewiński A. The influence of thiamazole, lithium carbonate, or prednisone administration on the efficacy of radioiodine treatment (1311) in hyperthyroid patients. Endokrynologia Polska/Polish J Endocrinols. 2010;61(1):56-61.

34. Oszukowska L, Knapska-Kucharska M, Makarewicz J, Lewiński A. The influence of thiamazole, lithium carbonate, or prednisone administration on the efficacy of radioiodine treatment ((131) I) in hyperthyroid patients. Endokrynologia Polska. 2010;61(1):56-61.

35. Brownlie BE, Turner JG, Ovenden BM, Rogers TG. Results of lithium- 131। treatment of thyrotoxicosis. J Endocrinol Investig. 1979;2(3):303-4. https:// doi.org/10.1007/BF03350422.

36. Oruch R, Elderbi MA, Khattab HA, Pryme IF, Lund A. Lithium: a review of pharmacology, clinical uses, and toxicity. Eur J Pharmacol. 2014;740:464-73. https://doi.org/10.1016/j.ejphar.2014.06.042.

37. de Jong JA, Verkooijen HM, Valk GD, Zelissen PM, de Keizer B. High failure rates after (131) I therapy in graves hyperthyroidism patients with large thyroid volumes, high iodine uptake, and high iodine turnover. Clin Nucl Med. 2013;38(6):401-6. https://doi.org/10.1097/RLU.0b013e3182817c78.

38. Turner JG, Brownlie BE, Rogers TG. Lithium as an adjunct to radioiodine therapy for thyrotoxicosis. Lancet. 1976;307(7960):614-5. https://doi.org/10.1 016/50140-6736(76)90419-0.

\section{Publisher's Note}

Springer Nature remains neutral with regard to jurisdictional claims in published maps and institutional affiliations.

\section{Ready to submit your research? Choose BMC and benefit from:}

- fast, convenient online submission

- thorough peer review by experienced researchers in your field

- rapid publication on acceptance

- support for research data, including large and complex data types

- gold Open Access which fosters wider collaboration and increased citations

- maximum visibility for your research: over $100 \mathrm{M}$ website views per year

At BMC, research is always in progress.

Learn more biomedcentral.com/submissions 